\title{
PRIMARY HODGKIN'S LYMPHOMA OF THE BREAST INITIALLY TREATED BY SURGICAL EXCISION AND AXILLARY DISSECTION
}

\author{
Ingrid Marton ${ }^{1}$, Zlatko Hrgović ${ }^{2}$ and Dubravko Habek ${ }^{1}$ \\ ${ }^{1}$ Department of Obstetrics and Gynecology, Sveti Duh University Hospital; \\ Croatian Catholic University, Zagreb, Croatia; \\ ${ }^{2}$ Praxis Prof. Zlatko Hrgovic, Frankfurt am Main, Frauenklinik Offenbach, Offenbach, Germany \\ SUMMARY - Primary breast lymphoma accounts for $0.04 \%-0.5 \%$ of all breast malignancies. \\ Primary non-Hodgkin's lymphomas of the breast are extremely rare and represent approximately \\ $0.38 \%-0.7 \%$ of all cases. Epstein-Barr virus (EBV) has been postulated to play an important role in \\ the pathogenesis of Hodgkin's lymphoma. We present a case of EBV-positive primary Hodgkin's \\ lymphoma of the breast. Although there is no sufficient data on this challenging diagnosis, it is known \\ that it could be misdiagnosed with inflammatory breast carcinoma. A crucial part of the proper histo- \\ pathologic diagnosis is immunohistochemistry. Different modalities of treatment include operative \\ procedure, chemotherapy and radiotherapy. Recent studies suggest chemotherapy and radiotherapy to \\ be initial treatment for patients with primary breast lymphomas.
}

Key words: Primary breast lymphoma; Hodgkin's lymphoma; Epstein-Barr virus; Immunohistochemistry

\section{Introduction}

Breast lymphoma is a rare condition, both as primary and metastatic disease. The primary form has an incidence ranging from $0.04 \%$ to $0.5 \%$ of all breast neoplasms, whereas the metastatic form has an incidence of approximately $0.07 \%$. Primary breast lymphoma accounts for $0.04 \%-0.5 \%$ of all breast malignancies ${ }^{1,2}$. Primary non-Hodgkin's lymphomas (NHL) of the breast are extremely rare and represent $0.38 \%$ $0.7 \%$ of all cases ${ }^{3}$. Epstein-Barr virus (EBV) has been postulated to play an important role in the pathogenesis of classical Hodgkin's lymphoma. We present a case of EBV-positive primary Hodgkin's lymphoma.

Correspondence to: Asst. Prof. Ingrid Marton, $M D$, PhD, Department of Obstetrics and Gynecology, Sveti Duh University Hospital, Sveti Duh 64, HR-10000 Zagreb, Croatia

E-mail: ingridmarton@gmail.com

Received September 8, 2016, accepted July 2, 2018

\section{Case Report}

A 66-year-old patient, para III, presented with 2 fast-growing solid, painless lumps in the upper right quadrant towards the axilla. Clinical examination revealed regularly shaped, mobile, painless lumps, without any significant changes on the skin. Ultrasonographic examination showed a homogeneous tumor within the axillary fossa that spread towards the right breast, measuring $8 \times 8 \mathrm{~cm}$ in diameter. All laboratory tests and tumor markers were within the normal range. Magnetic resonance imaging (MRI) of the abdomen and thorax did not reveal any primary or metastatic disease. The patient underwent total excision of the breast tumor and axillary dissection. Operative procedure and postoperative course were uneventful. A semi-solid tumor of $114 \mathrm{~g}$ within fatty tissue was extirpated and measured 10x7 $44 \mathrm{~cm}$ (Fig. 1). Histopathologic examination showed disruption of lymphatic architecture with fibrosis within 3 out of 8 lymph nodes, 


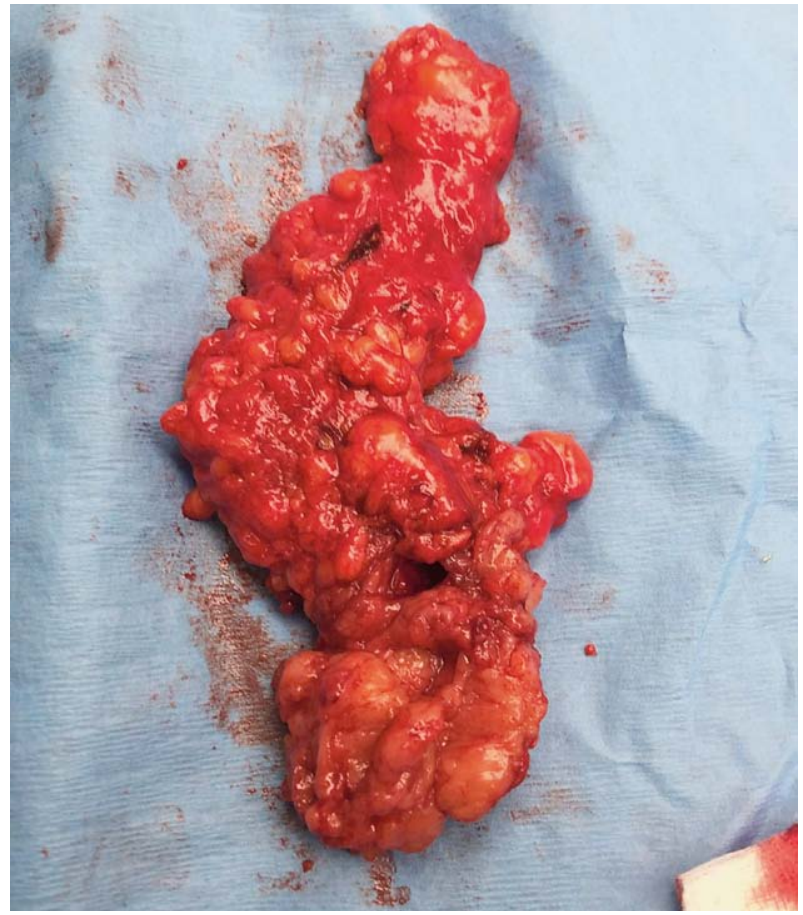

Fig. 1. Extirpated semi-solid tumor of $114 \mathrm{~g}$ measuring $10 \times 7 \times 4 \mathrm{~cm}$ within fatty tissue.

surrounded by eosinophilic infiltration, interfollicular atypical blasts, lymphomatous infiltration and histiocytes. Large multinuclear tumor cells with prominent nuclei and Reed-Sternberg cells were identified.

Blastoid cells were CD30 positive showing immunohistochemistry coexpression with CD15, LCA (CD45) and were $\mathrm{CD} 20$ negative, with $\mathrm{CD} 3$ positive T-lymphocytes. Five of 8 lymph nodes were without metastatic tumor tissue. The histopathology finding was suggestive of classical EBV-positive Hodgkin's lymphoma of mixed type. The patient was referred for further hemato-oncologic treatment.

\section{Discussion}

According to the literature, there are no sufficient data on malignant lymphoma of the breast. They may present both as a primary or secondary tumor, and both are rare. There are no morphological criteria to differentiate between the two ${ }^{4}$. Although primary breast lymphoma may appear at any age, the majority of patients are postmenopausal women . $^{5}$

Liu et al. ${ }^{1}$ have published data on 93 patients with primary breast lymphoma; according to Ann Arbor classification, $57 \%$ of patients were stage I, $23 \%$ were stage II, $4 \%$ stage III and 16\% stage IV. With 3-year survival, overall survival rate of $70 \%$ and high relapse rate of $48 \%$, it is considered to be a reason for concern. The patients having received chemotherapy and radiotherapy had better survival rate and lower relapse rate; therefore, the authors suggest that chemotherapy and radiotherapy be the initial treatment for patients with primary breast lymphoma. Zarnescu et al. ${ }^{5}$ have published a case report about unusual presentation of primary Hodgin's lymphoma of the breast. The tumor clinically presented as inflammatory breast cancer and core biopsy showed granulomatous mastitis, requiring surgical biopsy. This case showed that despite the uncommon clinical presentation, step-by-step diagnosis led to immunohistochemistry and proper diagnosis. Some recent studies have shown that primary nonHodgkin's lymphoma of the breast involving the axilla usually presents with the clinical appearance of inflammatory breast carcinoma without infiltration of the breast dermal lymphatics ${ }^{6}$. Tumor growth is usually accelerated ${ }^{7}$, which leads to enlarged tumors like the one described by Rahmat et al. ${ }^{8}$. EBV has been postulated to play an important role in the pathogenesis of Hodgkin's lymphoma. It is important to mention that immunodeficiency status such as HIV infection may predispose to EBV-associated Hodgkin's lymphoma 9 .

The aim of this case report is to highlight an uncommon oncologic disorder such as primary Hodgkin's lymphoma of the breast and particularly to emphasize its clinical, radiological and histopathologic presentations, and to discuss all the possible modalities of treatment (surgery, chemotherapy, radiotherapy).

\section{References}

1. Liu MT, Hsieh CY, Wang AY, Pi CP, Chang TH, Huang CC, et al. Primary breast lymphoma: a pooled analysis of prognostic factors and survival in 93 cases. Ann Saudi Med.2005;25(4):28893. http://dx.doi: 10.5144/0256-4947.2005.288

2. Darnell A, Gallardo X, Sentis M, Castaňer E, Fernandez E, Villajos M. Primary lymphoma of the breast: MR imaging features. A case report. Magn Reson Imaging. 1999;17(3):479-82. http://dx.doi: 10.1016/s073-0725x(98)00178-7.

3. Park YH, Kim SH, Choi SJ, RyooBY, Kang YK, Lee SS. Primary malignant lymphoma of the breast: clinicopathological study of nine cases. Leuk Lymphoma. 2004;45:327-30. http:// dx.doi: 10.1080/10428190310001597892 
4. Lamovec J, Wotherspoon A, Jacquemier J. Malignant lymphoma and metastatic tumors. In: Tavassoli FA, Devilee P (Eds.) WHO Classification of Tumors. Pathology and Genetics of Tumors of the Breast and Female Genital Organs. IARC Press, Lyon, 2003.

5. Zarnescu NO, Iliesiu A, Procop A, Tampa M, Matei C, Sajin $\mathrm{M}$, et al. A challenging case of primary breast Hodgkin's lymphoma. Maedica. 2015;10(1):44-7.

6. Taubaman KL, McKay MJ. Axillary lymphoma masquerading as inflammatory breast cancer. Biomed Imaging Interv J. 2006;2(3):36. http://dx.doi: 10.2349/biij.2.3.e36
7. Hoimes CJ, Selbst MK, Shafi NQ, Rose MG, Rosado MF. Hodgkin's lymphoma of the breast.J Clin Oncol. 2010;28(2):13. http://dx.doi: 10.1200/JCO.2009.23.1613

8. Rahmat K, Yip CH, D'Cruz NR, Yayaprasaqam KJ, Wong KT, et al. A rare case of Hodgkin's breast lymphoma masquerading as locally advanced carcinoma. Indian J Cancer. 2011;48(1):11820. http://dx.doi: 10.4103/0019-509X.76634

9. Mukherjee R, Mondal M, Banerjee D, Mukherjee M. Hodgkin's lymphoma of the breast: a rare occurrence. Clin Cancer Invest J. 2015;4(2):282-5.

Sažetak

\section{PRIMARNI HODGKINOV LIMFOM DOJKE INICIJALNO LIJEČEN KIRURŠKOM EKSCIZIJOM I AKSILARNOM DISEKCIJOM}

\section{Marton, Z. Hrgović i D. Habek}

Incidencija primarnih limfoma dojke kreće se od 0,04\% do 0,5\%. Primarni non-Hodgkinov limfom dojke iznimno je rijedak s učestalošću od oko 0,38\%-0,7\%. Dokazano je kako u patogenezi Hodgkinova limfoma sudjeluje Epstein-Barrov virus (EBV). Prikazujemo slučaj bolesnice s EBV-pozitivnim primarnim Hodgkinovim limfomom dojke. Iako do danas nema dovoljno literaturnih podataka o ovoj iznimno intrigantnoj bolesti, poznato je da je u najvećem broju slučajeva najozbiljniji diferencijalno dijagnostički problem upalni karcinom dojke. Temeljna odrednica histološke dijagnostike je imunohistokemija. Postoje različiti modaliteti liječenja koji uključuju operacijski zahvat te kemoterapiju i radioterapiju. Novije studije preporučuju kombinaciju kemoiradijacijskog liječenja kao inicijalnog tretmana primarnog limfoma dojke.

Ključne riječi: Primarni limfom dojke; Hodgkinov limfom; Epstein-Barrov virus; Imunohistokemija 